\title{
Candida auris ve Antifungal ilaçlara Direnç Mekanizmaları
}

\section{Candida auris and Mechanisms of Antifungal Drug Resistance}

\author{
Şehnaz ALP ${ }^{1}(I D)$, Sevtap ARIKAN AKDAĞLI ${ }^{2}(I D)$ \\ ${ }^{1}$ Hacettepe Üniversitesi Tıp Fakültesi, Enfeksiyon Hastalıkları ve Klinik Mikrobiyoloji Anabilim Dalı, Ankara. \\ ${ }^{1}$ Hacettepe University Faculty of Medicine, Department of Infectious Diseases and Clinical Microbiology, Ankara, Turkey. \\ ${ }^{2}$ Hacettepe Üniversitesi Tıp Fakültesi Tıbbi Mikrobiyoloji Anabilim Dalı, Ankara. \\ 2 Hacettepe University Faculty of Medicine, Department of Medical Microbiology, Ankara, Turkey.
}

Makale Atıfı: Alp ş, Arıkan Akdağlı S. Candida auris ve antifungal ilaçlara direnç mekanizmaları. Mikrobiyol Bul 2021;55(1):99-112.

\section{Öz}

Candida auris, 2009 yılında tanımlanmasının ardından günümüze kadar geçen süre içinde farklı bölge ve ülkelerde klinik örneklerden izole edilmiştir. Tanımlanmasında yaşanan sorunlar; antifungal ilaçlara direnç özelliği; hastane ortamında uzun süre varlığını sürdürebilme, ortam temizliğinde standart olarak kullanılan dezenfektanlara rağmen canlılığını koruyabilme, salgınlara neden olabilme potansiyeli ve görüldüğü bölge ve ülke sayısındaki belirgin artış nedeniyle üzerinde önemle durulan bir patojen haline gelen C.auris, neden olduğu invaziv enfeksiyonların tedavisinde yaşanan güçlükler, yüksek mortalite oranları ve sahip olduğu antifungal direnç özellikleriyle 2018 yılında Dünya'da en çok endişe duyulan ilk 10 mantar arasında yer almıştır. C.auris suşlarının \%60-90'ının flukonazole dirençli olduğu, \%10-30 kadarında amfoterisin B için yüksek minimum inhibitör konsantrasyon değerlerinin elde edildiği ve \%5'e varabilen oranlarda ekinokandinlere karşı direnç gösterebildiği belirtilmektedir. C.auris suşlarında antifungal ilaç direncinden sorumlu mekanizmaları ortaya koyabilmek ve in vitro direnç ile klinik yanıt arasındaki korelasyonu saptayabilmek amacıyla devam etmekte olan çalışmalardan elde edilen veriler bu konudaki bilgi birikimine önemli katkı sağlamıştır. Mevcut veriler, C.auris suşlarında antifungal ilaç direncine neden olan mekanizmaların diğer Candida türlerindeki antifungal direnç mekanizmaları ile ortak özellik gösterebilmekle birlikte, ayrışan yönlerinin de bulunduğunu ortaya koymaktadır. Bu derleme yazıda, C.auris'in antifungal ilaçlara azalmış duyarlılık veya direncinden ve hastane ortamında sıra dışı bir şekilde canlılığını sürdürebilme potansiyelinden sorumlu moleküler mekanizmalar ve biyofilm ilişkili faktörler tartışılmıştır.

Anahtar kelimeler: Candida auris; antifungal direnç; azoller; ekinokandinler; amfoterisin B; flusitozin.

\section{ABSTRACT}

Candida auris has been isolated from clinical samples in different regions and countries since it was first described in 2009. Due to the difficulties in identification; decreased susceptibility or resistance to antifungal agents; exceptional capacity to colonize and persist on surfaces; ability to survive despite standard disinfection procedures; and significant increase in the number of regions and countries with reported cases, C.auris has become a global health concern and placed among the World's ten most concerned fungi list in 2018 . It is stated that $60-90 \%$ of C.auris strains are resistant to fluconazole, 10 - 
$30 \%$ exhibit high minimum inhibitory concentration values for amphotericin $\mathrm{B}$, and up to $5 \%$ can be considered as resistant to echinocandins. Existing data obtained from ongoing research on molecular mechanisms of antifungal resistance in C.auris revealed some common features with other Candida species. However, diverging aspects are also reported. In this review article, current information on molecular mechanisms and biofilm-related factors responsible for decreased susceptibility or resistance to antifungal agents and unexpectedly high survival potential of C.auris have been discussed.

Keywords: Candida auris; antifungal resistance; azoles; echinocandins; amphotericin B; flucytosine.

\section{Giriş}

Candida haemulonii kompleksi içerisinde yer alan Candida auris, ilk olarak 2007 yılında Japonya'da bir hastanın dış kulak yolu akıntısından izole edilmiş, 2009 yılında tanımlanmış ve kulak kelimesinin Latince karşılığından yola çıkılarak 'auris' olarak isimlendirilmiştir $^{1-4}$. Aynı yıl içinde Güney Kore'de 15 farklı kulak izolatının saptanmış olması, C.auris'in özellikle kulakla sınırlı enfeksiyon oluşturan bir maya mantarı olduğunu düşündürmüştür ${ }^{4-6}$. Ancak, 2011 yılında Güney Kore'de kandidemi etkeni olarak izole edilmiş, geriye dönük taramalarda 1996 yılında kandidemiden sorumlu bir izolatın da bulunduğu belirlenmiştir ${ }^{7}$. Bu bildirimlerin ardından, farklı ülke ve bölgelerde kandidemi başta olmak üzere C.auris'e bağlı invaziv enfeksiyonların bildirimleri artmış ${ }^{8-13}$, bazı ülkelerde kandidemi epidemiyolojisinde değişimler ortaya çıkmış, Güney Afrika'daki birkaç merkezde C.auris en yaygın görülen fungal patojen olan C.albicans'ı geride bırakmıştır ${ }^{8,9}$. Ek olarak, Avrupa ve Amerika kıtasında, aylar boyunca devam eden ve yoğun bakım ünitelerinin kapanmasıyla sonuçlanan salgınlar da bildirilmiştir ${ }^{12,14,15}$.

C.auris türlerinin genom dizi analizlerinin yapılmasıyla, Doğu Asya, Güney Asya, Güney Afrika ve Güney Amerika olarak tanımlanan dört farklı klon varlığı ortaya konulmuştur $^{16,17}$. Henüz ülkemizde bildirimi yapılan C.auris izolatı bulunmamakla birlikte, 2018 yılında Avusturya'da belirlenen ilk olgunun, son yurt dışı seyahatini 2017 yılında Türkiye'ye yapıp Avusturya'ya dönmüş olan Türk asıllı bir Avusturya vatandaşı olması; ülkemizin uluslararası turizmde tercih edilmesi; seyahat rotaları üzerinde çok sayıda aktarma ve konaklamanın yapıldığı bir nokta olarak yer alması C.auris'in ülkemizde de ortaya çıkabileceğini düşündürmektedir ${ }^{3,18}$. Bu derleme yazıda, C.auris'in antifungal ilaçlara azalmış duyarlılık veya direncinden ve hastane ortamında sıra dışı bir şekilde canlılığını sürdürebilme potansiyelinden sorumlu moleküler mekanizmalar ve biyofilm ilişkili faktörler tartışılmıştır.

\section{C.auris ile Mücadelede Tanımlanmış Sorunlar}

Farklı hayvan modellerinde yapılan karşılaştırmalı çalışmalar, C.auris'te suşa özgü virülans düzeylerinin gözlendiğini ve virülansın çoğunlukla C.albicans'tan daha düşük olduğunu göstermiştir ${ }^{16,19-22}$. Bununla birlikte, C.auris salgınları sırasında, özellikle bağışıklık sistemi baskılanmış olgularda yüksek mortalite oranları bildirilmiş, diyabet, kardiyovasküler hastalık, pulmoner hastalık, sepsis veya antibiyotik tedavisi varlığının da önemli risk faktörleri olabileceği öne sürülmüştür ${ }^{16,23}$. C.auris suşlarının \%60-90 kadarında flukonazole direnç gözlendiği, \%10-30 kadarının amfoterisin B için yüksek minimum inhibitör 
konsantrasyon (MiK) değerleri ortaya koyduğu ve ekinokandinlere karşı da \%5'e varabilen oranlarda direnç gösterebildiği belirtilmektedir ${ }^{24-26}$. C.auris'in klinik kullanımdaki antifungal ilaçlara karşı yüksek MiK değerlerine sahip olması ${ }^{16,27}$ ve standart mikolojik yöntemlerle tanımlanmasında yaşanan güçlükler, C.auris ile mücadeleyi zorlaştırmaktadır ${ }^{8,24}$.

C.auris, hastane ortamında bir maya mantarından beklenmeyecek ölçüde yayılabilmiştir. Birleşik Krallık'taki bir hastanede, C.auris ile kolonize olmuş tek bir hastadan yayıIımla hastanede yatan diğer hastalar arasında ardışık olgular gözlenmiş, patojenin sağlık personelinde de saptanmış olması insandan insana bulaş varlığını akla getirmiştir. Ayrıca, hastanedeki yatakların kenarlarında, pencere pervazlarında, monitör ve diğer cihazların yüzeylerinde de saptanmış olması, diğer Candida türlerinin aksine C.auris'in hastane ortamında varlığını sürdürebildiğini göstermiş ve konu ile ilgili klasik kavramları değiştirmiştir $^{15,16}$. Birleşik Krallık'taki bir diğer hastanedeki salgına yönelik araştırmada, koltuk altı sıcaklık probları gibi yeniden kullanılabilir ekipmanların kullanımının hastalara bulaşta birincil etmen olduğu belirlenmiş, bu durum da C.auris'in yüzeylerde hayatta kalma yeteneğini ortaya koymuştur ${ }^{16,28}$.

C.auris'in hastane ortamında hayatta kalma kapasitesinin biyofilm oluşturma yeteneğine bağlı olabileceği düşünülmektedir. Biyofilm, hücrelerin mikrokoloniler halinde bir arada bulunduğu ve bir glukan matriks tarafından çevrelenerek korunduğu bir büyüme formudur. Genellikle, matriks ile çevrelenmiş hücreler sesil hücreler, matriksin dışındaki hücreler ise planktonik hücreler olarak tanımlanır. Yüksek düzey dezenfeksiyon işlemlerine rağmen C.auris'in yüzeylerden elimine edilebilmesinin bu yapılanma nedeniyle güç olduğu kabul edilmektedir $^{16,29}$. Ayrıca, hastaların tedavisinde kullanılan sistemik antifungal ilaçlara direnç gösterebilme özelliğinde de C.auris'in biyofilm oluşturma potansiyelinin rol oynadığı öne sürülmektedir. Biyofilm oluşturan hücrelerin yaralardan ve kateter uçlarından izole edilmiş olması, C.auris'in biyofilm formunda canlılığını sürdürebildiğine işaret ederken ${ }^{16,19}$, sesil hücrelerin bazı antifungal ilaçlara azalmış duyarlılık gösterdiği de ortaya konulmuştur ${ }^{16,30}$. Bunun yanı sıra, biyofilm oluşturan C.auris suşlarının artmış morbidite ve mortalite ile ilişkilendirilmiş olması, biyofilmin önemli bir virülans faktörü olduğunu da düşündürmüştür ${ }^{16,19}$.

C.auris, tanısı, tedavisi ve yayılımının önlenmesinde yaşanan güçlükler nedeniyle son 10 yılda dikkatleri üzerine çekmiş, 2018 yılında Dünya'da en çok endişe duyulan ilk 10 mantar listesine dahil edilmiştir ${ }^{27}$. C.auris'in kullanılmakta olan antifungal ilaçlara intrinsik (primer veya doğal) direncinin yanı sıra sekonder (kazanılmış) direnç gelişiminin de önemli bir sorun olduğu belirtilmektedir ${ }^{2,20}$.

Candida türlerinde, duyarlı bir suşun ilaca maruz kalması durumunda daha dirençli bir suş ile değişim ortaya çıkabilmektedir. Bu değişimde, ilaç suşun direnç geliştirmesine neden olmamakta, sadece popülasyondaki daha dirençli suşların seleksiyonunu sağlamaktadır. Bu dirençli türler kommensal organizmalar olarak sağlıklı kişilerde duyarlı türlerle bir arada bulunabilir. Enfeksiyon ortaya çıktığında, uygulanan antifungal tedavi duyarlı türlerin baskılanmasına ve daha dirençli türlerin baskın hale geçmesine olanak tanıyabilmektedir. 
Candida türlerinde, epigenetik direnç olarak tanımlanan, geçici gen ekspresyonu ile mantar hücre fenotipinde değişikliğin ortaya çıkması ve ilaç baskısı altında ilaca karşı geçici direnç oluşumu da gözlenebilmektedir. İlaç etkisi ortadan kalktığında suş tekrar duyarlı fenotipe dönebilmektedir.

Genetik mutasyon düşük bir oranda da olsa kendiliğinden ortaya çıkabilmektedir. İlaca maruz kalındığında, duyarlı suşlar yerine mutant suşlar popülasyonda baskın hale gelmekte ve ilaç etkisi ortadan kalktığında da mutasyonla kazandığı özelliklerini korumaktadır. Antifungal ilaç direncinde, enfeksiyona neden olan veya kommensal olarak bulunan mantar hücresinin miktarı önemlidir. Hücre sayısının artması direncin ortaya çıkmasına neden olabilecek mutasyon olasılığının artmasıyla sonuçlanmaktadır. Antifungal tedavi sırasında fungal hücre miktarında ciddi bir azalma olur. Genetik değişiklik göstererek bu darboğazdan kendilerini kurtarabilenler popülasyonda yeni kazandıkları özellikleriyle baskın hale gelerek dirençli suşların ortaya çıkmasına neden olabilirler ${ }^{31-35}$.

\section{Azol Grubu Antifungal İlaçlara Direnç Mekanizmaları}

Ökaryotik hücre zarında bulunan başlıca sterol kolesterol olduğu halde, mantar hücre zarındaki başlıca steroller ergosterol ve zimosteroldür. Hücre zarı, sitoplazmanın bütünlüğünün korunmasına katkıda bulunan ve hücrenin madde alışverişini düzenleyen yapıdır. Ergosterol, mantar hücre zarındaki sterollerin büyük bir bölümünü oluşturmaktadır. Hücre gelişimi için eser miktarlarda yeterli olabilen ergosterol, hücre döngüsünde önemli bir rol üstlenmektedir. Zarın akışkanlığını ve bütünlüğünü sağlamasının yanı sıra, hücre büyümesinde ve bölünmesinde görev alan kitin sentetaz gibi enzimlerin fonksiyonları için ergosterol gereklidir. Mantar hücre zarındaki ergosterolün yerini miktar açısından diğer steroller alabilmekte, ancak hücre döngüsündeki işlevini karşılayamamaktadır. Ergosterol, Candida türlerinde ERG11 geni tarafından kodlanan lanosterol 14-alfa-demetilaz enzimi aracılığıyla lanosterolün ergosterole dönüştürülmesiyle oluşmaktadır ${ }^{16,36,37}$.

Azol grubu antifungal ilaçlar, ergosterol sentez yolağındaki lanosterol 14-alfa-demetilazı hedef alarak lanosterolden ergosterol oluşumunu engelleyerek etkinlik gösterirler. Lanosterol demetilaz, aktif kısmında hem grubu içeren bir sitokrom P-450 enzimidir. Azoller, içerdikleri azot grubu ile hemdeki demir atomuna bağlanarak lanosterolün demetilasyonu için gerekli olan oksijen aktivasyonunu önler. Ayrıca, azollerdeki ikinci bir azot grubu lanosterol demetilazın apoproteini ile direkt olarak etkileşmektedir. Apoprotein ile etkileşen bu ikinci azot grubunun azollerin enzime özgüllüğünü belirlediği düşünülmektedir. Azollerin lanosterol 14-alfa-demetilaz enzimi üzerindeki inhibitör etkisi ergosterol sentezini engellediği gibi, mantar hücresinde 14-alfa-metil sterollerin birikmesine neden olur ve biriken metil steroller toksik etkiyle zar fosfolipidlerinin düzenini ve zara bağlı enzimlerin fonksiyonlarını bozarak mantar hücre döngüsünü ve zar geçirgenliğini bozar ${ }^{16,31,37}$.

Azol grubu antifungal ilaçlara direncin moleküler temelleri arasında, ergosterol sentezinde rol alan ve antifungal ilacın hedefi olan enzimin değişikliğe uğraması veya aşırı üretilmesi, ergosterol sentez yolağındaki başka bir enzimin değişikliğe uğratılması, ergos- 
terol yerine antifungal ilaca afinitesi düşük alternatif sterollerin sentezlenmesi ve antifungal ilacın hücre dışına atımını sağlayan mekanizmalar yer almaktadır.

\section{ERG 11 Geninde Nokta Mutasyonlar}

Lanosterolün ergosterole dönüşümünü sağlayan lanosterol 14-alfa-demetilaz enzimini kodlayan ERG11 geninin sıcak nokta ('hotspot': HS) bölgesinde aminoasit değişikliklerine neden olan mutasyonlar, azol grubu antifungallerin hedefi olan proteinin yapısında değişikliğe ve ilacın bağlanma afinitesinde azalmaya yol açarak azol direncine neden olabilmektedir ${ }^{16,25}$.

ERG11 genindeki, özellikle 105-165, 266-287 ve 405-488 numaralı amino asit dizileri arasında yer alan üç sıcak nokta bölgesindeki nokta mutasyonlarının Candida türlerinde azol grubu antifungal ilaçlara duyarlılığı azalttığı gösterilmiştir ${ }^{16,38}$. Ayrıca, ergosterol sentez yolağında rol alan C5-sterol desatüraz ve D22-sterol desatüraz enzimlerinin üretiminden sorumlu $E R G 3$ veya $E R G 5$ genindeki defekt, ergosterol yerine azol grubu antifungal ilaçlara afinitesi düşük alternatif sterollerin sentezlenmesine ve azol direncine neden olabilmektedir ${ }^{35,36}$.

Hindistan'daki olgulardan izole edilen 44 C.auris izolatının amino asit dizileri, sokak tipi (wild-type) C.albicans ERG11 gen dizisiyle karşılaştırıldığında 15 yanlış anlamlı ('missense') mutasyon bulunmuştur ${ }^{25}$. Yanlış anlamlı mutasyonlar, tek nükleotit değişimi sonucunda bir aminoasitin farklı bir aminoasite dönüşmesi ve bu dönüşümün fonksiyon değişimine neden olması ile sonuçlanan mutasyonlardır. Çalışmaya dahil edilen C.auris izolatlarında belirlenen 15 mutasyondan beşinin C.albicans'ta azol direnci ile ilişkisinin bilinmekte olan mutasyonlar olduğu, özellikle Y132F ile K143R olarak tanımlanan ve sıcak nokta bölgesinde yer alan iki varyantın çalışmadaki tüm dirençli izolatlarda saptandığı gösterilmiştir ${ }^{25}$. Columbia'da izole edilen C.auris suşlarının ERG11 geninde de Y132F ile K143R olarak tanımlanan varyantlar saptanmıştır. Bu iki mutasyonun Saccharomyces cerevisiae'de heterolog ekspresyonuyla azol grubu antifungaller için elde edilen MiK değerlerinin sokak tipi C.auris'in ERG11 genini eksprese eden S.cerevisiae suşlarında elde edilen değerlere göre iki kat yüksek olduğu bulunmuştur ${ }^{39}$.

\section{ERG11 Geninin Aşırı Ekspresyonu}

C.albicans'ta ERG11'in aşırı ekspresyonu da azol tedavisine dirençle ilişkilendirilmiştir. Lanosterol 14-alfa-demetilaz enziminin artan üretimi, antifungalin enzim üzerindeki inhibisyon kapasitesini aşarak tedaviye rağmen aktif sentezin devamını sağlar ${ }^{16,40}$. Gerçek zamanlı polimeraz zincir reaksiyonu (RT-PCR) ile flukonazol yokluğunda flukonazole duyarlı ve flukonazole dirençli suşlar arasında C.auris'in ERG11 geninin ekspresyonu açısından fark olmadığı ortaya konulmuştur. Flukonazol varlığında ise, flukonazole dirençli suşlarda flukonazol yokluğundaki kontrol suşa göre ERG11 ekspresyonun arttığı gösterilmiştir ${ }^{16,25}$. Bununla birlikte, flukonazolün ERG11 ekspresyonu üzerindeki etkisi flukonazole duyarlı suşlar üzerinde test edilmemiştir. Bu nedenle, flukonazol varlığında artan ERG11 ekspresyonunun dirençli suşlara özgü bir durum olduğu henüz kanıtlanmamıştır ${ }^{16}$. 


\section{Major Facilitator Superfamily (MFS) ve ATP Binding Cassette (ABC) Dışa Atım (Efflux) Pompaları}

Dışa atım pompaları, ekzojen veya endojen kaynaklı maddelerin hücre zarı boyunca taşınarak hücre dışına atılımlarından sorumlu proteinlerdir. Bu pompaların bir bölümü, ilaçları hücre dışına atarak hücre içi ilaç konsantrasyonlarını ve hücre üzerindeki etkilerini azaltabilmektedir. Ökaryotik hücreler, ilaç direnciyle ilişkili ATP binding casette transporters $(A B C)$ ve major facilitator superfamily (MFS) olmak üzere iki tip dışa atım pompası içermektedir. Dışa atım pompaları azol grubu antifungaller gibi hidrofobik veya lipofilik toksik moleküllerin aktif dışa atımından sorumludur ve dışa atım pompalarını kodlayan genlerin (örn: $C D R$ ve $M D R$ genleri) aşırı ekspresyonu Candida türlerinde azol grubu antifungal ilaçlara karşı en önemli direnç mekanizmalarından biridir ${ }^{16,41,42}$. Hindistan'da iki farklı çalışmada yapılan dizi analizlerinin sonucunda, C.auris suşlarının C.albicans'ın $A B C$ ve MFS taşıyıcılarına ortolog çok sayıda gen içerdiği saptanmıştır ${ }^{43,44}$. İsrail'de izole edilen C.auris suşları, floresan bir maddenin dışa atımının ölçülmesiyle yapılan karşılaştırmada C.glabrata ve C.haemulonii'ye göre daha yüksek bir ABC taşıyıcı aktivitesi göstermiştir ${ }^{20}$.

C.albicans'ta CDR1 geni, azol direncinde rol oynayan $A B C$ dışa atım pompasını kodlayan gendir. C.auris'te de CDR1'e homolog bir gen bulunmuş, bu genin silinmesi ile dirençli suşların 64-128 kat duyarlı hale gelebildiği gösterilmiştir ${ }^{45}$.

\section{Ekinokandinlere Direnç Mekanizmaları}

Beta $(1,3)$ D-glukan (BDG), çoğu patojenik mantarın hücre duvarında temel çapraz bağların bir bileşeni olarak görev yapan ve Candida türlerinde hücre duvar kütlesinin yaklaşık olarak \%30-60'ını oluşturan dallı polisakkaritlerdir. Ekinokandinler, BDG'nin sentezinde rol oynayan BDG sentaz enzim kompleksinin FKS1 ve FKS2 geni tarafından kodlanan iki katalitik alt birimini inhibe ederek etki gösterir. BDG sentezinin engellenmesi, hücre duvarındaki çapraz bağların oluşumunu bozarak belirgin ölçüde zayıflamış bir hücre duvar yapısına neden olur ve ozmotik kuvvete direnç gösteremeyen hücre duvarı parçalanır ${ }^{46,47}$.

C.albicans ve diğer C.auris dışı Candida türlerinde, FKS1 ve FKS2'nin aynı iki bölgesinde ekinokandin direncine yol açan birkaç mutasyon saptanmış ve sıcak nokta 1 ve 2 (HS1 ve HS2) olarak adlandırılmıştır. C.albicans suşlarındaki FKS1 geninde bu sıcak noktalar 641649 ve 1345-1365 numaralı amino asit dizileri arasında yer almaktadır ${ }^{16,48}$. Bu sıcak nokta bölgelerinin dizi analizinin yapıldığı C.auris suşlarında S639F amino asidindeki değişikliğin tüm ekinokandinlere dirençten sorumlu olduğu bulunmuş, araştırmanın yapıldığı 38 C.auris suşu arasında ekinokandinlere direnç gösteren 4 suşun tümünde bu değişiklik gözlenirken duyarlı olan 34 suşun hiçbirinde saptanmamıştır ${ }^{16,25}$. C.auris FKS1 genindeki bu pozisyonun C.albicans'taki karşılığının FKS1 geninde HS1'deki 645. bölgeye karşılık geldiği belirtilmiştir ${ }^{16}$. Ekinokandin dirençli C.auris suşlarında yapılan diğer çalışmalarda ise aynı bölgede S639Y ve S639P olarak tanımlanan farklı mutasyonların varlığı ortaya konulmuştur $^{49}$. S639P mutasyonu varlığının in vivo ekinokandin direncine neden olduğu deneysel fare modelinde de doğrulanmıştır ${ }^{50}$. 
C.auris genomunda FKS2'nin de bulunduğu bildirilmiş olmakla birlikte, günümüze kadar bu gende ekinokandin direnci ile ilişkili bir mutasyon saptanmamıştır ${ }^{16,44}$.

\section{Polyenlere Direnç Mekanizmaları}

Polyenler, ergosterol içeren membranları hedef alan ve 60 yılı aşkın bir süredir antifungal tedavide kullanılmakta olan bir gruptur. Polyenler, mantar hücre zarında bulunan sterollere geri dönüşümsüz olarak bağlanıp, kanallar oluşturarak zarın bütünlüğünü bozar. Bu durum, özellikle potasyum iyonları başta olmak üzere katyonların, şekerlerin ve metabolitlerin kaybı ve zardaki proton gradientinin bozulmasıyla sonuçlanır. Ayrıca, hücre zarında katalaz ve peroksidaz gibi oksidatif enzimlerin miktarının azalmasıyla da zar bütünlüğü bozulmaktadır ${ }^{16,31,51}$. Amfoterisin B, 1960 yılından bu yana sistemik antifungal tedavide yer almış bir polyendir. C.auris suşları arasında amfoterisin B'ye dirençli olanların varlığı bildirilmiş ancak dirence neden olan mekanizmalar yeterince aydınlatılamamıştı ${ }^{2,16}$. Candida türlerinde, hücre zarının sterol bileşimindeki değişikliklerin amfoterisin $B$ direncine neden olduğu vurgulanmaktadır ${ }^{52,53}$. Daha önce azol grubu antifungal ilaçlarla tedavi görülmüş olunması durumunda, azol grubu ilaçların mantar hücre zarında amfoterisin B'nin hedefi olan sterollerin miktarında azalmaya neden olması veya mantar hücresinde ergosterol yerine amfoterisin B'ye bağlanma afinitesi düşük sterollerin sentezlenmesi de amfoterisin B'ye dirence neden olabilmektedir. Mantarın hücre duvarında melanin içermesi durumunda, amfoterisin B’nin melanin tarafından absorbe edilmesi; mantar hücre zarında sterol/fosfolipid oranında meydana gelen değişiklikler ve mantarın durağan üreme fazında olması amfoterisin B direncinden sorumlu tutulmaktadır. Ayrıca, mantar hücresinde katalaz aktivitesinin artması oksidatif hasara duyarlıı̆ı̆ azalmasıyla amfoterisin B direncine aracılık etmektedir ${ }^{51}$. Ergosterol sentez yolağındaki enzimleri kodlayan ERG2, ERG3,ERG5, ERG6 ve ERG11 genlerindeki mutasyonların ilacın hedefi olan ergosterolün sentezinin azalmasına yol açtığı ve Candida türlerinde amfoterisin B direncinden sorumlu olduğu gösterilmiştir ${ }^{32,51}$. Rhodes ve arkadaşları ${ }^{49}$ Birleşik Krallık'ta amfoterisin B'ye azalmış duyarlılık gösteren 27 C.auris izolatında bu genlerdeki mutasyonları araştırmış ancak ilaca karşı azalmış duyarlılığı açıklayabilecek hiçbir varyant bulamamışlardır.

\section{Flusitozine Direnç Mekanizmaları}

Kimyasal olarak bir pirimidin olan flusitozin (5-florositozin) mantar hücresine sitozin permeaz aracılığıyla alınır ve sitozin deaminaz ile deamine edilerek 5-florourasile dönüşür. Memeli hücrelerinde sitozin deaminaz bulunmadığı veya çok az miktarda bulunduğu için flusitozinin mantara özgü olduğu kabul edilir. 5-florourasil, hücresel pirimidin oluşumunda rol alan urasil fosforibozil transferaz enzimi aracılığıyla 5-floroüridin monofosfata ve 5-floroüridin 5'-trifosfata dönüştürülür. 5-floroüridin monofosfat, DNA sentezi için esansiyel bir enzim olan timidilat sentetazı inhibe ederken, fungal RNA yapısına urasil yerine 5 -floroüridin $5^{\prime}$-trifosfatın katılmasıyla protein sentezi engellenir ${ }^{31,54,55}$. Sitozin permeaz enzimini kodlayan FCY2 genindeki nokta mutasyonlar flusitozinin hücre içine alımının azalmasına neden olurken sitozin deaminazı kodlayan FCY1 genindeki ve urasil 
fosforibozil transferazı kodlayan FUR1 genindeki nokta mutasyonlar ilacın aktivasyonunda ve metabolizmasında değişikliğe neden olur ${ }^{16,54-56}$. C.auris dışındaki Candida türlerinde, flusitozine kazanılmış dirençten özellikle FUR1 genindeki nokta mutasyonlar sorumlu tutulmaktadır ${ }^{16,38,54}$.

Rhodes ve arkadaşları ${ }^{49}$ flusitozine dirençli bir C.auris suşunun dizi analizini yapmış ve FUR1 geninde F211। olarak tanımlanan bir amino asit değişikliği saptamıştır. Ancak, bu yanlış anlamlı mutasyonun diğer Candida türlerinde bilinen bir karşılı̆ı bulunmadığı için, test edilen C.auris suşundaki flusitozin direncine neden olup olmadığını belirlemek üzere ek çalışmalara gereksinim olduğu belirtilmiştir ${ }^{16}$.

\section{Biyofilm Kaynaklı Antifungal Direnç}

Mantarların çoğunda gözlenen biyofilm oluşturma yeteneği antifungal ilaç direncine neden olan bir diğer özelliktir. Tıbbi önemi olan mantarların büyük bir bölümü (özellikle Candida, Cryptococcus, Aspergillus, Trichosporon, Coccidioides, Paracoccidioides, Trichophyton, Malassezia, Pneumocystis türleri, Mucorales takımındaki küf mantarları ve Histoplasma capsulatum) biyofilm oluşturabilen organizmalar olarak tanımlanırlar ${ }^{57}$.

Biyofilm oluşumu, uygun bir tabaka veya yüzeye planktonik hücrelerin yapışması, koIonizasyonu, ekstraselüler matriks üretimi, olgunlaşma ve dağılımı içeren ardışık bir süreçtir ${ }^{57,58}$. Ekstraselüler matriks, özellikle protein, nükleik asit, fosfolipid, lipid ve amiloid fibiriller ile ekstraselüler DNA içerebilen bir yapıya sahiptir. Ekstraselüler matriks, biyofilmin mekanik stabilitesini sağlayan, harici bir sindirim sistemi, besin, enerji ve geri dönüşüm kaynağı gibi işlev gören, hücreler arası iletişimin ve sinerjistik birliğin sağlanmasında hücrelerin etkileşiminde rol oynayan bir yapı olarak biyofilme oldukça önemli özellikler kazandırmaktadır ${ }^{57}$. Biyofilm yapısındaki mantar hücre yoğunluğu, sinyal molekülleri aracılığıyla iletişim ve koordinasyonun sağlanması ("quorum sensing"), dışa atım pompalarının aktivitesi, hücrelerin persistansı, ekstraselüler matriks ve ilaç hedeflerinin aşırı ekspresyonu gibi biyofilme özgü faktörler antifungal dirence katkı sağlamaktadır. Ayrıca, ekstraselüler matriksin, konak immün yanıtından korunmayı sağlayan, antimikrobiyallerin biyofilm içine fiziksel olarak geçişini ve böylece biyofilm içindeki miktarını azaltan bir yapı olarak antifungal direncine neden olduğu kabul edilmektedir ${ }^{57,59}$.

Biyofilm oluşumundaki erken döneme göre, ara dönem ve olgunlaşmanın gerçekleştiği dönemlerde biyofilm zarındaki ergosterol düzeylerinin belirgin olarak azaldığı, bu değişikliğin azol direncinden sorumlu olabileceği belirtilmektedir. Biyofilmdeki dışa atım pompalarının antifungal direnç gelişimindeki rolünün araştırıldığı çalışmalarda, biyofilm oluşumunun erken döneminde (ilk 24 saat) CDR gen ekspresyonu baskın halde bulunurken, 24 saatten sonrasındaki dönemde sadece MDR1'in aşırı ekspresyonu saptanmış ve C.albicans'ın planktonik halde azollere duyarlı iken biyofilm içinde direnç gösterdiği belirlenmiştir ${ }^{57,60}$. Dışa atım pompalarının ekpresyonunun özellikle ekstraselüler matriks oluşumu gerçekleşmeden önceki erken dönemde antifungal direncinden sorumlu olduğuna ilişkin bulgular C.glabrata, C.tropicalis ve A.fumigatus ile yapılan çalışmalarda da saptanmıştır ${ }^{57}$. 
Biyofilm oluşumu sırasında, ekstraselüler matriksin karbonhidrat yapısındaki başlıca bileşeni beta-1,3 glukandır. Bu yapının, azolleri, ekinokandinleri, pirimidinleri ve polyenleri bir sünger gibi tutarak C.albicans'ın oluşturduğu biyofilmlerdeki antifungal direncinden sorumlu olduğu düşünülmektedir. Non-albicans Candida türlerinde de ekstraselüler matriksin beta-1,3 glukan içerdiği ve özgül bağlanmalar aracılığıyla azol direncine neden olduğu belirtilmektedir ${ }^{57}$. Biyofilm yapısındaki persistan hücreler, hücre duvar sentezi yapmayan veya az miktarda sentez yapan dormant (uyuyan) hücrelerdir. Persistan hücrelerin, mayaların oluşturduğu biyofilmlerde bulunurken planktonik popülasyonda bulunmadığı, antimikrobiyal ilaçların persistan hücrelerdeki hedef moleküllerine bağlanarak biriktiği ancak hücre ölümünü gerçekleştiremediği belirtilmektedir ${ }^{57,59}$.

C.auris'in oluşturduğu biyofilm içindeki sesil hücrelerin test edilen antifungal ilaçlar için saptanan MiK değerleri, biyofilm dışındaki planktonik hücreler için saptanan değerlerden belirgin olarak yüksek bulunmuştur. Mik değerlerindeki bu farkın vorikonazole karşı 4 kat, amfoterisin B'ye karşı 20 kat, mikafungine karşı 60 kata kadar çıkabildiği belirtilmiştir ${ }^{16,30}$. Benzer şekilde, minimal biyofilm eradikasyon konsantrasyonlarının, ekinokandin ve azol Mik değerlerinden 512 kat daha yüksek olduğu gösterilmiştir ${ }^{16,61}$. Bu durumların varlığı daha önce C.albicans için de ortaya konulmuştur ${ }^{62}$. Yükselmiş MiK değerlerinden sorumlu mekanizmaları aydınlatmak amacıyla Kean ve arkadaşları tarafından yapılan çalışmada, MFS ve $A B C$ dışa atım pompalarını kodlayan genlerin ekspresyonlarının planktonik hücrelere kıyasla sesil hücrelerde arttığı ('upregulation') (2-4 kat), buna karşılık gelen proteinlerin aktivitesinde de 2 kat artış olduğu bulunmuştur. Bununla birlikte, dışa atım pompası inhibitörleri ile muamele edildiğinde, 12 saat sonra sesil hücrelerin antifungal duyarlılığında 4-16 kat artış ortaya çıkmıştır. Bu bulgu, dışa atım pompalarının sesil hücrelerin antifungallere direncinde önemli bir rol oynadığını düşündürmüştür ${ }^{16,63}$. C.albicans'ta, ekzopolimer matriksin tüm antifungal ilaç sınıflarına spesifik olmayan bir şekilde bağlandığı ve antifungalleri hücrelerin dışında tuttuğu bilinmektedir ${ }^{16,57}$. Candida türleri ortak bir polisakkarit yapısını paylaştığından, aynı mekanizmanın C.auris'te de korunmuş olabileceği öne sürülmüş $^{16,63}$ ve Dominguez ve arkadaşlarının ${ }^{64}$ in vitro ve in vivo çalışmalarıyla doğrulanmıştır.

\section{Hastane Ortamında Kalıcılık}

C.auris'in yüzeylerdeki kolonizasyon ve kalıcılık kapasitesi, sıra dışı bir özellik olarak kabul edilmektedir. C.albicans'a göre nemli yüzeylerde oldukça uzun süre dayanabilmekte $\mathrm{e}^{16,65}$, ciltte ve plastik yüzeylerde kolonizasyon kapasitesi ile bilinen C.parapsilosis'e benzer şekilde yüzeylerde metabolik aktivitesini uzun süre devam ettirebilmektedir ${ }^{16,65,66}$.

C.auris'in yüzeylerdeki uzun süreli sağ kalım nedenlerini irdeleyen çalışmalar, sıcaklığa ve diğer stres faktörlerine karşı artmış bir çevresel direncin ortaya çıkmasının veya biyofilm oluşumunun sorumlu olduğunu öne sürmüştür ${ }^{16,29}$. Günümüze kadar çevresel yüzeylerden biyofilm oluşturan bir suşun izole edilmemiş olması, biyofilm hipotezi üzerindeki tartışmaların devam etmesine neden olmuştur. Bununla birlikte, her iki olasılığın birbirini dışlamadığı, hatta biyofilm oluşumunun artmış çevresel stres direncinin nedeni olabileceği de belirtilmiştir ${ }^{16}$. C.auris'in hastane ortamındaki kalıcılığı, bu patojenin 
dezenfeksiyon işlemlerine gösterdiği direnç nedeniyle artmaktadır. Sodyum hipoklorit ve perasetik asidin paslanmaz çelik, polimer (polyester lameller) ve selüloz yüzeylerdeki etkinliği araştırılmıştır. Her iki dezenfektan da C.auris hücrelerine karşı önemli ölçüde etkinlik gösterebilmiş olmakla birlikte gözeneksiz yüzeylere (paslanmaz çelik ve polyester lameller) sodyum hipoklorit uygulandıktan sonra bazı canlı hücrelerin kaldığı saptanmıştır. Daha yüksek konsantrasyonlarda (10.000 ppm sodyum hipoklorit) ve daha uzun süre (5 dakika) uygulandığında, koloni sayısında belirgin azalma olduğu ancak patojenin tamamen ortadan kaldırılamadığı gösterilmiştir ${ }^{16,29}$. Yüksek düzey bir dezenfektan olan perasetik asit için yapılan denemelerde, paslanmaz çeliğin aksine polimer yüzeylerdeki uygulamanın ardından üreme gözlenmemiş, C.glabrata ve C.albicans ile yapılan denemelerde de benzer sonuçlar alınmıştır ${ }^{16,67}$.

ABD Hastalık Kontrol ve Korunma Merkezleri [Centers for Disease Control and Prevention (CDC)], yapılan çalışmaların sonuçlarına dayanarak C.auris için dezenfeksiyon amacıyla Clostridium difficile sporlarına karşı etkili dezenfektanların kullanılmasını önermektedir. Alternatif olarak, \%0.5-1.4'lük hidrojen peroksit veya izopropil alkol ve/veya etil alkol eklenmiş dörtlü (kuvaterner) amonyum bileşiklerinin de kullanılabileceği belirtilmektedir ${ }^{16,68}$. Ultraviyole-C'nin de yüzey dezenfeksiyonu için bir aday olabileceği belirtilmiş, uygun mesafeden yeterli süre uygulandığında C.auris kolonilerini ortadan kaldırabildiği gösterilmiştir. Bununla birlikte, bu yöntemin hastane ortamında kullanılması önerilmeden önce daha ileri çalışmaların yapılmasına gereksinim olduğu da vurgulanmıştır ${ }^{16,69}$.

\section{Sonuç}

C.auris'in patojenite ve virülans kapasitesi oldukça endişe vericidir. Bunun yanı sıra, dünyanın farklı bölgelerinde olguların ve salgınların görülmüş olması ve izole edilen suşların klinik kullanımda olan antifungal ilaçlara azalmış duyarlılık veya direnç göstermesi, C.auris'in neden olduğu enfeksiyonlarda endişenin daha da büyümesine neden olmuştur. Araştırmacılar, C.auris suşlarında gözlenen antifungal dirençten veya azalmış duyarlılıktan sorumlu mekanizmaları açıklayabilmek için diğer Candida türleri, özellikle C.albicans ile ilgili mevcut bilgilerden yararlanmıştır. ERG 11'deki nokta mutasyonlarının ve $A B C$ taşıyıCısı Cdr1'in aşırı ekspresyonunun flukonazol duyarlıı̆ıını azalttığı kanıtlanmış, FKS1'deki bir amino asit değişikliğinin C.auris'in ekinokandinlere duyarlılı̆ını azalttığı gösterilmiştir. Flusitozine dirençli bir C.auris suşunda FUR1'de mutasyon varlığı tanımlanmıştır ancak bu mutasyonun dirençten sorumlu olduğunun kanıtlanması gerekmektedir. İlaç duyarıılığını azalttığı gösterildiği için biyofilm oluşumunun ayrı bir direnç mekanizması olduğu düşünülmektedir. Bununla birlikte, biyofilmin C.albicans gibi iyi bilinen türlerde bile yeterince anlaşılamayan, araştırılması zor bir karmaşık yapı olduğunun akılda tutulması, bu büyüme formunda yer alan tüm süreçleri aydınlatmak için daha ileri araştırmaların yapılması gerektiği belirtilmektedir ${ }^{16}$. C.auris'in hastane ortamında yüzeylere yapışabilme ve standart dezenfeksiyon işlemlerine karşı koyabilme yeteneği, sağlık hizmeti ilişkili enfeksiyonlara neden olma ve antifungal ilaçlara direnç veya azalmış duyarlılık gösterebilme potansiyeli, önemli bir sorun olarak güncelliğini korumaya devam etmektedir. 


\section{ÇIKAR ÇATIŞMASI}

Yazarlar bu makale ile ilgili herhangi bir çıkar çatışması bildirmemişlerdir.

\section{KAYNAKLAR}

1. Satoh K, Makimura K, Hasumi Y, Nishiyama Y, Uchida K, Yamaguchi H. Candida auris sp. nov., a novel ascomycetous yeast isolated from the external ear canal of an inpatient in a Japanese hospital. Microbiol Immunol 2009; 53: 41-4.

2. Lockhart SR. Candida auris and multidrug resistance: Defining the new normal. Fungal Genet Biol 2019; 131: 103243.

3. Gülmez D. Candida auris: on yılda dünyaya yayılmayı başaran fungal patojen. FLORA 2019; 24: $263-71$.

4. Kean R, Brown J, Gulmez D, Ware A, Ramage G. Candida auris: a decade of understanding of an enigmatic pathogenic yeast. J Fungi (Basel) 2020; 6: 30.

5. Kim MN, Shin JH, Sung H, Lee K, Kim EC, Ryoo N, et al. Candida haemulonii and closely related species at 5 university hospitals in Korea: identification, antifungal susceptibility, and clinical features. Clin Infect Dis 2009; 48: e57-61.

6. Spivak ES, Hanson KE. Candida auris: an emerging fungal pathogen. J Clin Microbiol 2018; 56: e01588-17.

7. Lee WG, Shin JH, Uh Y, Kang MG, Kim SH, Park KH, et al. First three reported cases of nosocomial fungemia caused by Candida auris. J Clin Microbiol 2011; 49: 3139-42.

8. de Cássia Orlandi Sardi J, Silva DR, Soares Mendes-Giannini MJ, Rosalen PL. Candida auris: epidemiology, risk factors, virulence, resistance, and therapeutic options. Microb Pathog 2018; 125: 116-21.

9. Adam RD, Revathi G, Okinda N, Fontaine M, Shah J, Kagotho E, et al. Analysis of Candida auris fungemia at a single facility in Kenya. Int J Infect Dis 2019; 85: 182-7.

10. van Schalkwyk E, Mpembe RS, Thomas J, Shuping L, Ismail H, Lowman W, et al; GERMS-SA. epidemiologic shift in candidemia driven by Candida auris, South Africa, 2016-2017. Emerg Infect Dis 2019; 25: 1698-707.

11. Mathur P, Hasan F, Singh PK, Malhotra R, Walia K, Chowdhary A. Five-year profile of candidaemia at an Indian trauma centre: High rates of Candida auris blood stream infections. Mycoses 2018; 61: 674-80.

12. Calvo B, Melo AS, Perozo-Mena A, Hernandez M, Francisco EC, Hagen F, et al. First report of Candida auris in America: Clinical and microbiological aspects of 18 episodes of candidemia. J Infect 2016; 73: 369-74.

13. Rudramurthy SM, Chakrabarti A, Paul RA, Sood P, Kaur H, Capoor MR, et al. Candida auris candidaemia in Indian ICUs: analysis of risk factors. J Antimicrob Chemother 2017; 72: 1794-801.

14. Ruiz-Gaitán A, Moret AM, Tasias-Pitarch M, Aleixandre-López Al, Martínez-Morel H, Calabuig E, et al. An outbreak due to Candida auris with prolonged colonisation and candidaemia in a tertiary care European hospital. Mycoses 2018; 61: 498-505.

15. Schelenz S, Hagen F, Rhodes JL, Abdolrasouli A, Chowdhary A, Hall A, et al. First hospital outbreak of the globally emerging Candida auris in a European hospital. Antimicrob Resist Infect Control 2016; 5: 35.

16. Chaabane F, Graf A, Jequier L, Coste AT. Review on antifungal resistance mechanisms in the emerging pathogen Candida auris. Front Microbiol 2019; 10: 2788.

17. Lockhart SR, Etienne KA, Vallabhaneni S, Farooqi J, Chowdhary A, Govender NP, et al. Simultaneous Emergence of multidrug-resistant Candida auris on 3 continents confirmed by whole-genome sequencing and epidemiological analyses. Clin Infect Dis 2017; 64: 134-40.

18. Pekard-Amenitsch S, Schriebl A, Posawetz W, Willinger B, Kolli B, Buzina W. Isolation of Candida auris from ear of otherwise healthy patient, Austria, 2018. Emerg Infect Dis 2018; 24: 1596-7.

19. Borman AM, Szekely A, Johnson EM. Comparative pathogenicity of united kingdom isolates of the emerging pathogen Candida auris and other key pathogenic Candida species. mSphere 2016; 1: e00189-16.

20. Ben-Ami R, Berman J, Novikov A, Bash E, Shachor-Meyouhas Y, Zakin S, et al. Multidrug-resistant Candida haemulonii and C.auris, Tel Aviv, Israel. Emerg Infect Dis 2017; 23: 195-203. 
21. Fakhim H, Vaezi A, Dannaoui E, Chowdhary A, Nasiry D, Faeli L, et al. Comparative virulence of Candida auris with Candida haemulonii, Candida glabrata and Candida albicans in a murine model. Mycoses 2018; 61: 377-82.

22. Wang X, Bing J, Zheng Q, Zhang F, Liu J, Yue H, et al. The first isolate of Candida auris in China: clinical and biological aspects. Emerg Microbes Infect 2018; 7: 93.

23. Osei Sekyere J. Candida auris: A systematic review and meta-analysis of current updates on an emerging multidrug-resistant pathogen. Microbiologyopen 2018; 7: e00578.

24. Arikan-Akdagli S, Ghannoum M, Meis JF. Antifungal resistance: specific focus on multidrug resistance in Candida auris and secondary azole resistance in Aspergillus fumigatus. J Fungi (Basel) 2018; 4: 129.

25. Chowdhary A, Prakash A, Sharma C, Kordalewska M, Kumar A, Sarma S, et al. A multicentre study of antifungal susceptibility patterns among 350 Candida auris isolates (2009-17) in India: role of the ERG11 and FKS1 genes in azole and echinocandin resistance. J Antimicrob Chemother 2018; 73: 891-9.

26. Arendrup MC, Prakash A, Meletiadis J, Sharma C, Chowdhary A. comparison of EUCAST and CLSI reference microdilution MICs of eight antifungal compounds for Candida auris and associated tentative epidemiological cutoff values. Antimicrob Agents Chemother 2017; 61: e00485-17.

27. Hyde KD, Al-Hatmi AMS, Andersen B, Boekhout T, Buzina W, Dawson TL Jr, et al. The world's ten most feared fungi. Fungal Diversity 2018; 93: 161-94.

28. Eyre DW, Sheppard AE, Madder H, Moir I, Moroney R, Quan TP, et al. A Candida auris outbreak and its control in an intensive care setting. $N$ Engl J Med 2018; 379: 1322-31.

29. Kean R, Sherry L, Townsend E, McKloud E, Short B, Akinbobola A, et al. Surface disinfection challenges for Candida auris: an in-vitro study. J Hosp Infect 2018; 98: 433-6.

30. Sherry L, Ramage G, Kean R, Borman A, Johnson EM, Richardson MD, et al. Biofilm-forming capability of highly virulent, multidrug-resistant Candida auris. Emerg Infect Dis 2017; 23: 328-31.

31. White TC, Marr KA, Bowden RA. Clinical, cellular, and molecular factors that contribute to antifungal drug resistance. Clin Microbiol Rev 1998; 11: 382-402.

32. Arendrup MC, Patterson TF. Multidrug-resistant Candida: epidemiology, molecular mechanisms, and treatment. J Infect Dis 2017; 216(suppl3): S445-S51.

33. Arastehfar A, Lass-Flörl C, Garcia-Rubio R, Daneshnia F, Ilkit M, Boekhout T, et al. The quiet and underappreciated rise of drug-resistant invasive fungal pathogens. J. Fungi 2020; 6: 138.

34. Robbins N, Caplan T, Cowen LE. Molecular evolution of antifungal drug resistance. Annu Rev Microbiol 2017; 71: 753-75.

35. Bhattacharya S, Sae-Tia S, Fries BC. Candidiasis and mechanisms of antifungal resistance. Antibiotics 2020; 9 : 312.

36. Parks LW, Casey WM. Physiological implications of sterol biosynthesis in yeast. Annual Review of Microbiology 1995; 49: 95-116.

37. UpToDate. Pharmacology of azoles. Available from: https://www.uptodate.com/contents/pharmacologyof-azoles (Accessed date: 28 October 2020)

38. Vandeputte P, Ferrari S, Coste AT. Antifungal resistance and new strategies to control fungal infections. Int J Microbiol 2012; 2012: 713687.

39. Healey KR, Kordalewska M, Jiménez Ortigosa C, Singh A, Berrío I, Chowdhary A, et al. Limited ERG11 mutations identified in isolates of Candida auris directly contribute to reduced azole susceptibility. Antimicrob Agents Chemother 2018; 62: e01427-18.

40. Lopez-Ribot JL, McAtee RK, Lee LN, Kirkpatrick WR, White TC, Sanglard D, et al. Distinct patterns of gene expression associated with development of fluconazole resistance in serial Candida albicans isolates from human immunodeficiency virus-infected patients with oropharyngeal candidiasis. Antimicrob Agents Chemother 1998; 42: 2932-7.

41. Schuetzer-Muehlbauer M, Willinger B, Egner R, Ecker G, Kuchler K. Reversal of antifungal resistance mediated by $A B C$ efflux pumps from Candida albicans functionally expressed in yeast. Int J Antimicrob Agents 2003; 22: 291-300. 
42. Morschhäuser J, Barker KS, Liu TT, BlaB-Warmuth J, Homayouni R, Rogers PD. The transcription factor Mrr1p controls expression of the MDR1 efflux pump and mediates multidrug resistance in Candida albicans. PLoS Pathog 2007; 3: e164.

43. Chatterjee S, Alampalli SV, Nageshan RK, Chettiar ST, Joshi S, Tatu US. Draft genome of a commonly misdiagnosed multidrug resistant pathogen Candida auris. BMC Genomics 2015; 16: 686.

44. Sharma C, Kumar N, Pandey R, Meis JF, Chowdhary A. Whole genome sequencing of emerging multidrug resistant Candida auris isolates in India demonstrates low genetic variation. New Microbes New Infect 2016; 13: 77-82.

45. Rybak JM, Doorley LA, Nishimoto AT, Barker KS, Palmer GE, Rogers PD. Abrogation of triazole resistance upon deletion of cdr1 in a clinical isolate of Candida auris. Antimicrob Agents Chemother 2019; 63: e00057-19.

46. Martins IM, Cortés JC, Muñoz J, Moreno MB, Ramos M, Clemente-Ramos JA, et al. Differential activities of three families of specific beta $(1,3)$ glucan synthase inhibitors in wild-type and resistant strains of fission yeast. J Biol Chem 2011; 286: 3484-96.

47. UpToDate. Pharmacology of echinocandins. Available from: https://www.uptodate.com/contents/ pharmacology-of-echinocandins (Accessed date: 28 October 2020)

48. Park S, Kelly R, Kahn JN, Robles J, Hsu MJ, Register E, et al. Specific substitutions in the echinocandin target Fks1p account for reduced susceptibility of rare laboratory and clinical Candida sp. isolates. Antimicrob Agents Chemother 2005; 49: 3264-73.

49. Rhodes J, Abdolrasouli A, Farrer RA, Cuomo CA, Aanensen DM, Armstrong-James D, et al. Genomic epidemiology of the UK outbreak of the emerging human fungal pathogen Candida auris. Emerg Microbes Infect 2018; 7: 43.

50. Kordalewska M, Lee A, Park S, Berrio I, Chowdhary A, Zhao Y, et al. Understanding echinocandin resistance in the emerging pathogen Candida auris. Antimicrob Agents Chemother 2018; 62: e00238-18.

51. de-Oliveira SC, Rodrigues AG. Candida albicans antifungal resistance and tolerance in bloodstream infections: the triad yeast-host-antifungal. Microorganisms 2020; 8: 154.

52. Haynes MP, Chong PL, Buckley HR, Pieringer RA. Fluorescence studies on the molecular action of amphotericin B on susceptible and resistant fungal cells. Biochemistry 1996; 35: 7983-92.

53. Nolte FS, Parkinson T, Falconer DJ, Dix S, Williams J, Gilmore C, et al. Isolation and characterization of fluconazole- and amphotericin B-resistant Candida albicans from blood of two patients with leukemia. Antimicrob Agents Chemother 1997; 41: 196-9.

54. Spampinato C, Leonardi D. Candida Infections, causes, targets, and resistance mechanisms: traditional and alternative antifungal agents. Biomed Res Int 2013; 2013: 204237.

55. Gopinathan S, Janagond AB, Agatha D, Thenmozhivalli PR. Detection of FUR1 gene in 5-Flucytosine resistant Candida isolates in vaginal candidiasis patients. J Clin Diagn Res 2013; 7: 2452-5.

56. Waldorf AR, Polak A. Mechanisms of action of 5-fluorocytosine. Antimicrob Agents Chemother 1983; 23: 79-85.

57. Scorzoni L, de Paula e Silva ACA, Marcos CM, Assato PA, de Melo WCA, de Oliveira HC, et al. Antifungal therapy: new advances in the understanding and treatment of mycosis. Front Microbiol 2017; 8: 36.

58. Fanning S, Mitchell AP. Fungal biofilms. PLoS Pathog 2012; 8: e1002585.

59. Lewis, K. Persister cells, dormancy and infectious disease. Nat Rev Microbiol 2007; 5: 48-56.

60. Ramage G, Bachmann S, Patterson TF, Wickes BL, López-Ribot JL. Investigation of multidrug efflux pumps in relation to fluconazole resistance in Candida albicans biofilms. J Antimicrob Chemother 2002; 49: 973-80.

61. Romera D, Aguilera-Correa JJ, Gadea I, Viñuela-Sandoval L, García-Rodríguez J, Esteban J. Candida auris: a comparison between planktonic and biofilm susceptibility to antifungal drugs. J Med Microbiol 2019; 68: 1353-8.

62. Hawser SP, Douglas LJ. Resistance of Candida albicans biofilms to antifungal agents in vitro. Antimicrob Agents Chemother 1995; 39: 2128-31.

63. Kean R, Delaney C, Sherry L, Borman A, Johnson EM, Richardson MD, et al. Transcriptome assembly and profiling of Candida auris reveals novel insights into biofilm-mediated resistance. mSphere 2018; 3: e00334-18. 
64. Dominguez EG, Zarnowski R, Choy HL, Zhao M, Sanchez H, Nett JE, et al. Conserved role for biofilm matrix polysaccharides in Candida auris drug resistance. mSphere 2019; 4: e00680-18.

65. Piedrahita CT, Cadnum JL, Jencson AL, Shaikh AA, Ghannoum MA, Donskey CJ. Environmental surfaces in healthcare facilities are a potential source for transmission of Candida auris and other Candida Species. Infect Control Hosp Epidemiol 2017; 38: 1107-9.

66. Welsh RM, Bentz ML, Shams A, Houston H, Lyons A, Rose LJ, et al. Survival, persistence, and isolation of the emerging multidrug-resistant pathogenic yeast Candida auris on a plastic health care surface. J Clin Microbiol 2017; 55: 2996-3005.

67. Cadnum JL, Shaikh AA, Piedrahita CT, Sankar T, Jencson AL, Larkin EL, et al. Effectiveness of disinfectants against Candida auris and other Candida species. Infect Control Hosp Epidemiol 2017; 38: 1240-3.

68. Centers for Disease Control and Prevention (CDC). Infection prevention and control for Candida auris. Available from: https://www.cdc.gov/fungal/candida-Candida/c-auris-infection-control.html (Accessed date: 28 October 2020).

69. de Groot T, Chowdhary A, Meis JF, Voss A. Killing of Candida auris by UV-C: Importance of exposure time and distance. Mycoses 2019; 62: 408-12. 